\title{
The Effect of Corporate Cash Holding on Idiosyncratic Risk: Evidence from China
}

\author{
Yueting Cai ${ }^{1, a, \dagger}$, Yunran $\operatorname{Liu}^{2, b, \dagger}$, Xinyi $\mathrm{Li}^{3, \mathrm{c}, \dagger}$ \\ ${ }^{1}$ School of Economic and Management, Tsinghua University, China \\ ${ }^{2}$ Department of Business and Management Studies, Lancaster University Management School, Lancaster University, \\ Lancaster, LA1 4YW, UK \\ ${ }^{3}$ School of Economic and Management, Beijing Forestry University, China \\ *Corresponding author.Email: ${ }^{\text {*}}$ caiyt19@mails.tsinghua.edu.cn \\ ${ }^{\dagger}$ These authors contributed equally.
}

\begin{abstract}
We examine the effect of corporate cash holding on idiosyncratic risk. We find that corporate cash holding in China is positively associated with idiosyncratic risk. The association is robust to several robustness checks, including adopting an alternative method, fixed-effects model, and the inclusion of some possibly omitted variables. Further analyses demonstrate that the impact of corporate cash holding on idiosyncratic risk is more pronounced in firms that are nonSOEs, non-Big 4 auditors, having lower institutional shareholdings, and a lower growth rate. Our research enriches the role of corporate cash holding in corporate governance.
\end{abstract}

Keywords: Cash holding, Corporate idiosyncratic risk, Corporate governance, Agency problem.

\section{INTRODUCTION}

Corporate cash holding is the number of assets held by a firm in the form of cash and cash equivalents (e.g., shortterm bonds and money market funds). In general, firms reserve cash to overcome different kinds of unexpected situations.

Despite the necessity of cash holding as a financial resource in firms, this practice is controversial. Two opposing arguments exist in some literature regarding the effects of corporate cash holding from two opposing perspectives. One view is that there is a positive effect of cash holding on lowering the risks of losing investment opportunities. Opler, Pinkowitz, Stulz, and Williamson find that firms with strong growth opportunities and take part in riskier activities tend to hold more cash than other firms in case of missing investment opportunities. Firms hold liquid assets to ensure that they will keep investing when cash flow is too low relative to investment and when outside funds are expensive [1]. This idea is also previously articulated by Myers \& Majluf, who explain that due to the interests of stockholders and creditors being opposed to each other, corporate cash holdings can make firms have the ability to take advantage of good investment opportunities in time [2].
The other view is that too much cash holding leads to a negative effect on corporate governance. Jensen and Meckling find that agency costs are associated with excess cash holding. In other words, managers can use corporate cash holdings to capture their own benefits [3].

Idiosyncratic risk is a great indicator to describe the risks faced by individual firms. However, owing to the lack of attention to the idiosyncratic risk of Chinese firms, there is little research focusing on how cash holding affects idiosyncratic corporate risks. Previous studies have probed several determinants affecting idiosyncratic risk, including firm-level volatility [4], institutional ownership and leverage [5], industry concentration [6], the new listing effect [7], corporate social performance [8], and investment [9]. We choose a new perspective and aim to explore the impact of firms' cash holding on idiosyncratic corporate risk.

To examine how cash holding affects idiosyncratic corporate risk, we collect the data of Chinese listed firms over the period 2007-2018. We conclude that corporate cash holding is positively associated with idiosyncratic risk. The association is robust to several robustness checks, including 
adopting an alternative method, fixed-effects model, and the inclusion of some possibly omitted variables. Further analyses demonstrate that the impact of firms' cash holding on idiosyncratic corporate risk is more pronounced in firms that are non-SOEs, non-Big 4 auditors, having higher analyst, lower institutional shareholdings, and lower growth rate. Further analyses demonstrate that the impact of firms' cash holding on idiosyncratic corporate risk is more pronounced in firms that are non-SOEs, non-Big 4 auditors, having lower institutional shareholdings, and lower growth rate.

This study contributes to the extant literature. First, to the best of our knowledge, this study is the first to examine how cash holding impacts idiosyncratic corporate risk. Our findings provide support to the notion that corporate cash holding is positively associated with idiosyncratic risk. In this regard, we believe that this study adds an important piece to the corporate cash holding and idiosyncratic risk.

Second, our study broadly complements corporate determination literature by exploring corporate cash holding could affect idiosyncratic risk.

Third, our study also enriches the literature on idiosyncratic corporate risk. Prior studies have examined the impacts of idiosyncratic risk on firm-level volatility [4], institutional ownership and leverage [5], industry concentration [6], the new listing effect [7], corporate social performance [8], and investment [9]. Our study examines the impact of idiosyncratic risk on cash holding, thus enriching the literature by exploring a new perspective.

The remainder of this study is organized as follows. We develop our hypothesis in Section 2. Section 3 describes the research design, including sample selection, model specification, and variable measurement. The empirical results are discussed in Section 4. Section 5 provides robustness checks, and Section 6 performs further analyses, including adopting an alternative method, a fixed-effects model, and the inclusion of some omitted variables. Section 7 concludes the paper.

\section{HYPOTHESES DEVELOPMENT}

Early studies state that aggressive operating strategies and increased competition are the sources of idiosyncratic risk [10]. According to these two ideas, researchers have examined several causes of idiosyncratic risk, including firm-level volatility [4], institutional ownership and leverage [5], industry concentration [6], the new listing effect [7], corporate social performance [8], and investment [9]. These factors increase the uncertainty within the firm or weaken the firm's competitiveness. In conclusion, aggressive strategies and increased competition are kinds of determinants of idiosyncratic risk.

Theoretically, there exist two different perspectives on the effect of corporate cash holding on idiosyncratic risk.
One perspective is that the imperfection of the capital market is one of the key determinants of cash holding behaviour. If a firm can obtain external funds at no cost, there is no need to hold cash internally [11]. When it believes that its cash flow is lower than expected, it will obtain funds to continue operations for free [1]. However, in reality, the cost of external financing is high, resulting in firms having to hold a certain amount of current assets.

Following this idea, researchers argue that there is three motive for corporate cash holding, which are transactional motive [12], precautionary motive [13], and speculative motive [14]. Cash holding can ensure the liquidity of the corporate assets to deal with asymmetric information in the capital market. There may be unpredictable expenditures in the daily operation that require a certain level of cash to respond in time. Moreover, it may be optimal for firms to hold enough cash to meet the need for potential investment projects. In summary, cash holding may reduce the uncertainty encountered by firms.

The other perspective is that there is an opportunity cost associated with cash and cash equivalent [15]. The return on capital of cash is very low, and large holding will make firms lose many investment opportunities to not withstand the fierce competition in the industry. Prior studies state that a high level of cash holding may vary due to the inaction of managers [16]. Conflict of interest between business owners and resource users could reduce the incentive of managers to act in the best interest of shareholders. In other words, agency problems may increase corporate risk.

Therefore, we propose two competing hypotheses for the effect of corporate cash holding on idiosyncratic risk.

H1a: Corporate cash holding decreases idiosyncratic risk, other things being equal.

H1b: Corporate cash holding increases idiosyncratic risk, other things being equal.

\section{RESEARCH DESIGN}

\subsection{Construction of sample}

Our sample initially comprised all listed firms on the SHSE and SZSE from 2007 to 2018 . We choose 2007 as the beginning year of our sample period because China implemented the new Accounting Standards for Business Enterprises (ASBE) in that year. The financial data used in this study are obtained from China Stock Market Accounting Research (CSMAR) system. Furthermore, we exclude financial firms (e.g., banks, mortgage 
companies, and securities companies) as the Balance Sheets are different from other companies. We drop Special Treatment (ST) firms and eliminate data with missing values. We also winsorize the top and bottom $1 \%$ of all of the continuous variables to exclude the effect of outliers. Finally, we get a usable sample of 21535 firm-year observations.

\subsection{Models}

The hypotheses to be tested are that idiosyncratic risk is a function of corporate cash holdings and other control variables. The basic empirical model employed is:

$$
\begin{aligned}
& I R_{t+1} \\
& =\beta_{0}+\beta_{1} \text { Cash }_{t} \\
& +\sum_{q=2}^{m} \beta_{q}\left(\text { Control Variable }_{t}\right)+\varepsilon_{t+1}
\end{aligned}
$$

where $\beta_{i}$ represents regression coefficients; $\varepsilon$ is an error term; and Control Variable contains $I R_{t}$, Size $e_{t}$ Age $e_{t}$ Lev $v_{t}$,

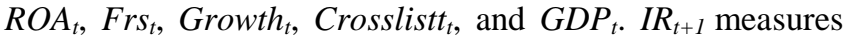
idiosyncratic risk computed from the Fama-French three factor model, whereas Cash $_{t}$ represents the percentage of cash and cash equivalent over total assets less cash and cash equivalent holding by firm $i$ at time $t$. We also control for industry and year fixed effect. A negative (positive) $\beta_{1}$ suggests that corporate cash holdings tend to decrease (increase) idiosyncratic risk.

\subsection{Variables}

\subsubsection{Dependent variable: Corporate idiosyncratic risk}

Following Fama and French (1993), Brown (2004), Boehme (2009), Carhart (1997), we employ two measures of idiosyncratic volatility. Both measures are based on Fama-French three factor model. Specifically, we estimate the following Fama-French three factor model regression:

$$
\begin{aligned}
\mathrm{r}_{1, \mathrm{t}}-\mathrm{r}_{\mathrm{f}, \mathrm{t}}=\alpha_{\mathrm{i}, \mathrm{t}}+ & \beta_{\mathrm{MKT}, \mathrm{i}, \mathrm{t}}\left(\mathrm{MKT}_{\mathrm{t}}-\mathrm{r}_{\mathrm{f}, \mathrm{t}}\right) \\
& +\beta_{\mathrm{SMB}, \mathrm{i}, \mathrm{t}} \mathrm{SMB}_{\mathrm{t}} \\
& +\beta_{\mathrm{HML}, \mathrm{i}, \mathrm{t}} \mathrm{HML}_{\mathrm{t}}+\varepsilon_{\mathrm{i}, \mathrm{t}}
\end{aligned}
$$

where $r_{f, t}$ is the return of risk free in week $t$, and $M K T_{t}$ is the return of market investment portfolio interest in week $t$, and $S M B_{, t}$ is the return of investment portfolio interest based on the enterprise size in week $t$, and $H M L_{t}$ is the return of investment portfolio interest based on book-tomarket equity, and $\alpha_{i, t}$ is the regression constant term of stock $i$ in week $t, \varepsilon_{i, t}$ is the regression residuals of stock $i$ in week $t$.

Using the sample standard deviation of regression residuals to calculate the idiosyncratic volatility of the stock in this month, we calculate the idiosyncratic volatility of stock $i$ in $t$ month as

$$
\operatorname{IVOL}_{\mathrm{i}, \mathrm{t}}=\operatorname{Sk}\left(\varepsilon_{\mathrm{i}, \mathrm{t}}\right) \times \sqrt[2]{\mathrm{T}_{\mathrm{i}, \mathrm{t}}}
$$

where $\operatorname{Sk}\left(\varepsilon_{i, t}\right)$ is the standard deviation of $\varepsilon_{i, t}$, and $T_{, i, t}$ is the trading day of stock $i$ in month $t$.

\subsubsection{Test variable: Cash $_{t}$}

Following prior studies, we use the ratio of corporate cash and cash equivalents to the total corporate assets to measure the cash holding level of the corporate. At the same time, to avoid the estimation error caused by single variable estimation, we use the ratio of monetary capital to total assets as the robust test.

\subsubsection{Control variables}

We control several factors that have been shown to affect future stock price heterogeneous risk in prior studies. (1) Enterprise size $\left(\right.$ Size $\left._{t}\right)$. Small size enterprises are not sufficiently responsive to emergencies, especially some small enterprises with weak competitiveness. Thus the idiosyncratic corporate volatility is relatively large. We use the natural logarithm of the book value of total assets in year $t$ to measure the enterprise size. (2) Return on assets $(R O A)$. Corporate profitability reflects the strong competitiveness and performance and sufficient internal capital of a corporation. We use the return on assets ( $R O A)$ to measure Corporate profitability. (3) Enterprise age (Age). We use the natural logarithm of the firm listing age to measure the enterprise age. (4) Payout ratio $(D I V)$. The Payout ratio is related to the corporate decision. It directly determines how many assets that corporate have for reproduction. The prior studies show that corporate Pay more dividends have less cash holding, and corporate uncertainty is higher. Thus the idiosyncratic risk of corporate is higher. (5) Corporate idiosyncratic risk (IR). The firm idiosyncratic risk, which shows the risks faced by individual corporate. (6) Leverage (Lev). Leverage results from using borrowed capital as a funding source when investing in expanding the firm's asset base and generating returns on risk capital.

\section{EMPIRICAL ANALYSES}

\subsection{Descriptive statistics}

Table 1 provides descriptive statistics for the variables used in our analysis. The mean of $I R_{t+1}$ is 0.892 . The firm in our sample has an average Size of 21.880, an average $\mathrm{Age}_{t}$ of 2.728, an average $\mathrm{Lev}_{t}$ of 0.448 , an average $R_{0} a_{t}$ of 0.039 , an average Growth $_{t}$ of 0.221 , an average CrossList $t_{t}$ of 0.067 , an average $G D P_{t}$ of 0.121 . 
Table 1. Descriptive statistics. This table reports descriptive statistics on idiosyncratic risk, cash holding, and control variables for the sample in 2007-2018.

\begin{tabular}{ccccccc}
\hline Variable & $\mathrm{N}$ & Mean & S.D. & Min & P50 & Max \\
\hline IR $R_{t+1}$ & 21,535 & 0.892 & 0.272 & 0.309 & 0.877 & 1.606 \\
Cash $_{t}$ & 21,535 & 0.242 & 0.294 & 0.009 & 0.146 & 1.839 \\
Size $_{t}$ & 21,535 & 21.880 & 1.282 & 19.330 & 21.710 & 25.790 \\
Age $t$ & 21,535 & 2.728 & 0.364 & 1.609 & 2.773 & 3.401 \\
Lev $_{t}$ & 21,535 & 0.448 & 0.214 & 0.051 & 0.446 & 0.957 \\
Roa $_{t}$ & 21,535 & 0.039 & 0.054 & -0.184 & 0.036 & 0.199 \\
Frst & 21,535 & 0.357 & 0.151 & 0.088 & 0.338 & 0.751 \\
Growth & 21,535 & 0.221 & 0.551 & -0.591 & 0.124 & 3.931 \\
CrossList & 21,535 & 0.067 & 0.250 & 0.000 & 0.000 & 1.000 \\
GDP $t$ & 21,535 & 0.121 & 0.047 & 0.070 & 0.104 & 0.231 \\
\hline
\end{tabular}

\subsection{Correlation analysis}

Table 2 reports the results of correlation tests of the key variables. The results suggest that corporate cash holding is positively associated with idiosyncratic risk. The results also show that all the correlations between the independent variables are relatively low.

\subsection{Univariate analysis}

Table 3 reports the results of univariate tests of the key variables used in this study. To test the relationship between corporate cash holdings and idiosyncratic risk, we divide the sample into two groups: (1) containing low cash holdings and (2) containing high cash holdings. The $t$-Value of $\mathrm{Cash}_{t}$ is -6.284 . This means that firms with low cash holdings have lower idiosyncratic risk than firms with high cash holdings.

\subsection{Multivariate results}

Table 4 displays the regression model results (1) described in Section 3.2 used to test our hypotheses. Column (1) contains the industry and year fixed effects regression result without adding control variables. As shown in Table 4, the estimated coefficient of the variable $\mathrm{Cash}_{t}$ in column (1) is 0.055 and significantly positive at the $1 \%$ level.

Column (2) contains the industry and year fixed effects regression results after adding control variables.
We find that the coefficient of the variable $\mathrm{Cash}_{t}$ in column (2) is 0.027 , still statistically significant positive at the $1 \%$ level, indicating that corporate cash holdings increase idiosyncratic risk. $\mathrm{H} 1 \mathrm{~b}$ is supported by the positive and significant coefficients of Casht in regressions using model (1).

Firms with higher cash holdings, smaller size, higher leverage, and lower ROA are associated with higher idiosyncratic risk. 
Table 2. This table reports the results of correlation analysis of idiosyncratic risk, cash holding, and control variables for the sample in 2007-2018.

\begin{tabular}{|c|c|c|c|c|c|c|c|c|c|c|c|}
\hline & $I R_{t}$ & $\mathrm{Cash}_{t}$ & $I R_{t}$ & Size $_{t}$ & $A g e_{t}$ & Lev $t_{t}$ & $\operatorname{Roa}_{t}$ & $F r s_{t}$ & Growth $_{t}$ & $\begin{array}{c}\text { CrossLi } \\
\text { st }_{t}\end{array}$ & $G D P_{t}$ \\
\hline$I R_{t+1}$ & 1.000 & $\begin{array}{c}0.048 * * \\
*\end{array}$ & $\begin{array}{c}0.340^{* *} \\
*\end{array}$ & $\begin{array}{c}- \\
0.265^{* *} \\
*\end{array}$ & $\begin{array}{c}- \\
0.160^{* *} \\
*\end{array}$ & $\begin{array}{c}- \\
0.014^{* *}\end{array}$ & -0.011 & 0.008 & $\begin{array}{c}0.040 * * \\
*\end{array}$ & $\begin{array}{c}- \\
0.036 * * \\
*\end{array}$ & $\begin{array}{c}0.154 * * \\
*\end{array}$ \\
\hline Cash $_{t}$ & $\begin{array}{c}0.059 * * \\
*\end{array}$ & 1.000 & $\begin{array}{c}0.065^{* *} \\
*\end{array}$ & $\begin{array}{c}- \\
0.236^{* *} \\
*\end{array}$ & $\begin{array}{c}- \\
0.112 * * \\
*\end{array}$ & $\begin{array}{c}- \\
0.401 * * \\
*\end{array}$ & $\begin{array}{c}0.328^{* *} \\
*\end{array}$ & $\overline{-}^{-}$ & $\begin{array}{c}0.069 * * \\
*\end{array}$ & $\begin{array}{c}- \\
0.060 * * \\
*\end{array}$ & $\begin{array}{c}0.043 * * \\
*\end{array}$ \\
\hline$I R_{t}$ & $\begin{array}{c}0.339 * * \\
*\end{array}$ & $\begin{array}{c}0.057 * * \\
*\end{array}$ & 1.000 & $\begin{array}{c}- \\
0.265 * * \\
*\end{array}$ & $\begin{array}{c}- \\
0.193^{* *} \\
*\end{array}$ & -0.001 & $\begin{array}{c}0.033^{* *} \\
*\end{array}$ & 0.009 & $\begin{array}{c}0.055^{* *} \\
*\end{array}$ & $\begin{array}{c}- \\
0.030 * * \\
*\end{array}$ & $\begin{array}{c}0.034 * * \\
*\end{array}$ \\
\hline Size $_{t}$ & $\begin{array}{c}- \\
0.268 * * \\
*\end{array}$ & $\begin{array}{c}- \\
0.237 * * \\
*\end{array}$ & $\begin{array}{c}- \\
0.267 * * \\
*\end{array}$ & 1.000 & $\begin{array}{c}0.200^{* *} \\
*\end{array}$ & $\begin{array}{c}0.447 * * \\
*\end{array}$ & $\begin{array}{c}- \\
0.082^{* *} \\
*\end{array}$ & $\begin{array}{c}0.201 * * \\
*\end{array}$ & -0.011 & $\begin{array}{c}0.219 * * \\
*\end{array}$ & $\begin{array}{c}- \\
0.114^{* *} \\
*\end{array}$ \\
\hline$A g e_{t}$ & $\begin{array}{c}- \\
0.143^{* *} \\
*\end{array}$ & $\begin{array}{c}- \\
0.156^{* *} \\
*\end{array}$ & $\begin{array}{c}- \\
0.171 * * \\
*\end{array}$ & $\begin{array}{c}0.168^{* *} \\
*\end{array}$ & 1.000 & $\begin{array}{c}0.152^{* *} \\
*\end{array}$ & $\begin{array}{c}- \\
0.119^{* *} \\
*\end{array}$ & $\begin{array}{c}- \\
0.140^{* *} \\
*\end{array}$ & $\begin{array}{c}- \\
0.099 * * \\
*\end{array}$ & $\begin{array}{c}0.121 * * \\
*\end{array}$ & $\begin{array}{c}- \\
0.233 * * \\
*\end{array}$ \\
\hline Lev $_{t}$ & $\begin{array}{c}- \\
0.016^{* *}\end{array}$ & $\begin{array}{c}- \\
0.394^{* *} \\
*\end{array}$ & -0.001 & $\begin{array}{c}0.430^{* *} \\
*\end{array}$ & $\begin{array}{c}0.165^{* *} \\
*\end{array}$ & 1.000 & $\begin{array}{c}- \\
0.411 * * \\
*\end{array}$ & $\begin{array}{c}0.064 * * \\
*\end{array}$ & 0.010 & $\begin{array}{c}0.113^{* *} \\
*\end{array}$ & $\begin{array}{c}0.073 * * \\
*\end{array}$ \\
\hline $\operatorname{Roa}_{t}$ & -0.004 & $\begin{array}{c}0.250^{* *} \\
*\end{array}$ & $0.014 * *$ & $\begin{array}{c}- \\
0.039^{* *} \\
*\end{array}$ & $\begin{array}{c}- \\
0.096^{* *} \\
*\end{array}$ & $\begin{array}{c}- \\
0.381 * * \\
*\end{array}$ & 1.000 & $\begin{array}{c}0.089 * * \\
*\end{array}$ & $\begin{array}{c}0.300 * * \\
*\end{array}$ & $\begin{array}{c}- \\
0.023 * * \\
*\end{array}$ & $\begin{array}{c}0.078^{* *} \\
*\end{array}$ \\
\hline$F r s_{t}$ & 0.005 & -0.002 & 0.003 & $\begin{array}{c}0.243^{* *} \\
*\end{array}$ & $\begin{array}{c}- \\
0.138^{* *} \\
*\end{array}$ & $\begin{array}{c}0.063^{* *} \\
*\end{array}$ & $\begin{array}{c}0.095^{* *} \\
*\end{array}$ & 1.000 & 0.003 & $\begin{array}{c}0.055^{* *} \\
*\end{array}$ & $\begin{array}{c}0.036^{* *} \\
*\end{array}$ \\
\hline Growth $_{t}$ & $\begin{array}{c}0.048^{* *} \\
*\end{array}$ & 0.006 & $\begin{array}{c}0.042 * * \\
*\end{array}$ & $-0.013 *$ & $-0.012 *$ & $\begin{array}{c}0.051 * * \\
*\end{array}$ & $\begin{array}{c}0.180 * * \\
*\end{array}$ & $\begin{array}{c}0.026^{* *} \\
*\end{array}$ & 1.000 & $\begin{array}{c}- \\
0.039 * * \\
*\end{array}$ & $\begin{array}{c}0.178^{* *} \\
*\end{array}$ \\
\hline $\begin{array}{l}\text { CrossLi } \\
\text { st } t_{t}\end{array}$ & $\begin{array}{c}- \\
0.032 * * \\
*\end{array}$ & $\begin{array}{c}- \\
0.059 * * \\
*\end{array}$ & $\begin{array}{c}- \\
0.028^{* *} \\
*\end{array}$ & $\begin{array}{c}0.283^{* *} \\
*\end{array}$ & $\begin{array}{c}0.104 * * \\
*\end{array}$ & $\begin{array}{c}0.114 * * \\
*\end{array}$ & $\begin{array}{c}- \\
0.020^{* *} \\
*\end{array}$ & $\begin{array}{c}0.053 * * \\
*\end{array}$ & $\begin{array}{c}- \\
0.026 * * \\
*\end{array}$ & 1.000 & $\begin{array}{c}0.029 * * \\
*\end{array}$ \\
\hline$G D P_{t}$ & $\begin{array}{c}0.175^{* *} \\
*\end{array}$ & $\begin{array}{c}0.046^{* *} \\
*\end{array}$ & $\begin{array}{c}0.186^{* *} \\
*\end{array}$ & $\begin{array}{c}- \\
0.133^{* *} \\
*\end{array}$ & $\begin{array}{c}- \\
0.270 * * \\
*\end{array}$ & $\begin{array}{c}0.098^{* *} \\
*\end{array}$ & $\begin{array}{c}0.048 * * \\
*\end{array}$ & $\begin{array}{c}0.038 * * \\
*\end{array}$ & $\begin{array}{c}0.079 * * \\
*\end{array}$ & $\begin{array}{c}0.038^{* *} \\
*\end{array}$ & 1.000 \\
\hline
\end{tabular}




\section{ROBUSTNESS CHECKS}

In this section, we perform three robustness checks separately to examine the sensitivity of our results, which are adopting an alternative method, fixed-effects model, and the inclusion of some omitted variables.

The method we adopted to measure the level of cash holding was dividing cash and cash equivalents by the percentage of total assets minus cash and cash equivalents. To ensure accurate results, we adopt an alternative method that divides monetary funds plus short-term investments by total assets. We then reestimate the regressions of the model (1). As reported in Table 5, the coefficients of cash holding in column (1) are significantly positive at the $1 \%$ level. This implies that our finding of a positive relationship between cash holding and idiosyncratic risk is not driven by choice of measuring method.

To mitigate possible problems which may arise from omitting time-invariant firm-specific characteristics, we re-estimate the regression of model (1) using the fixed effects model and report the results in Table 5 . According to Table 5, the estimated coefficient of the variable Casht in column (2) is significantly positive at the $5 \%$ level. This indicates that time-invariant firmspecific characteristics do not drive our results.

To alleviate the endogeneity caused by omitted correlated variables, we add to model (1) several potential omitted variables, including enterprise nature, enterprise size, gender of executives, age of executives, and whether the executives are directors. According to the results shown in Table 5, the coefficient on cash holding in column (3) remains significantly positive. Therefore, our results are robust to the inclusion of other control variables to alleviate the effect of omitted correlated variables.

\section{FURTHER ANALYSES}

To make our findings more abundant and precise, we further study that corporate characteristics have a more significant positive relationship between cash holding and idiosyncratic risk. The characteristics that we take into consideration are the nature of property rights, Big 4 auditors, institutional investors' percentage, and growth rate.

\subsection{The Nature of Property Right}

We divide the sample into two subsets: the firms that are SOEs and those that are not SOEs. Then we reestimate model (1) with the two subsets separately. As reported in Table 6, the estimated coefficient of cash holding in column (1) is 0.012 and is not significant. On the contrary, the coefficient of cash holding in column (5) is 0.029 , significant at the $1 \%$ level. This indicates that the effect of cash holdings on future corporate idiosyncratic risk is more pronounced in firms that are not-SOEs.

\subsection{Big 4 Auditors}

We divide the sample into two subsets: the firms that appoint Big 4 auditors to provide annual reports auditing service and those that do not appoint Big 4 auditors. Then we re-estimate model (1) with the two subsets separately. As reported in Table 6, the estimated coefficient of cash holding in column (2) is 0.014 and is not significant. On the contrary, the coefficient of cash holding in column (6) is 0.025 , significant at the $1 \%$ level. This indicates that the effect of cash holdings on future corporate idiosyncratic risk is more pronounced in firms that do not appoint Big 4 auditors.

\subsection{Analyst Level}

We divide the sample into two subsets: the firms whose institutional shareholdings are above the median of the same year and industry and whose institutional shareholdings are below the median. Then we reestimate model (1) with the two subsets separately. As reported in Table 6, the estimated coefficient of cash holding in column (3) is 0.019 and is significant at the $5 \%$ level. On the contrary, the coefficient of cash holding in column (7) is 0.034 , significant at the $1 \%$ level. This indicates that the effect of cash holdings on future corporate idiosyncratic risk is more pronounced in firms whose institutional shareholdings are above the median of the same year and industry.

\subsection{Institutional Investors}

We divide the sample into two subsets: the firms with high growth rates and low growth rates. Then we re-estimate model (1) with the two subsets separately. As reported in Table 6, the estimated coefficient of cash holding in column (4) is 0.022 and is significant at the 5\% level. On the contrary, the coefficient of cash holding in column (8) is 0.028 , significant at the $1 \%$ level. This indicates that cash holdings on future corporate idiosyncratic risk are more pronounced in firms with low growth rates.

According to the above findings, we find that the positive relationship between cash holding and idiosyncratic corporate risk becomes more pronounced in non-SOEs, non-Big 4 auditors, lower institutional shareholdings, and lower growth rate.

\subsection{Growth Rate}

We divide the sample into two subsets: the firms with high growth rates and low growth rates. Then we re-estimate model (1) with the two subsets separately. As reported in Table 6, the estimated coefficient of cash 
holding in column (5) is 0.022 and is significant at the 5\% level. On the contrary, the coefficient of cash holding in column (10) is 0.028 , significant at the $1 \%$ level. This indicates that cash holdings on future corporate idiosyncratic risk are more pronounced in firms with low growth rates.
According to the above findings, we find that the positive relationship between cash holding and idiosyncratic corporate risk become more pronounced in firms that are non-SOEs, non-Big 4 auditors, having higher analyst, lower institutional shareholdings, and

lower growth rate.

Table 3. Univariate analysis.

\begin{tabular}{|c|c|c|c|c|c|c|}
\hline Two-sample & $\mathrm{t}$ & test & with & equal & variances & \\
\hline Variables & G1(0) & Mean1 & G2(1) & Mean2 & MeanDiff & t-Value \\
\hline Cash $_{t}$ & 11,224 & 0.230 & 10,311 & 0.255 & -0.025 & $-6.284 * * *$ \\
\hline Size $_{t}$ & 11,224 & 22.150 & 10,311 & 21.590 & 0.565 & $33.083 * * *$ \\
\hline $\mathrm{Age}_{t}$ & 11,224 & 2.771 & 10,311 & 2.682 & 0.089 & $18.129 * * *$ \\
\hline Lev $_{t}$ & 11,224 & 0.451 & 10,311 & 0.446 & 0.005 & $1.670^{*}$ \\
\hline $\operatorname{Roa}_{t}$ & 11,224 & 0.040 & 10,311 & 0.039 & 0.001 & $1.986 * *$ \\
\hline FrSt & 11,224 & 0.355 & 10,311 & 0.359 & -0.003 & -1.600 \\
\hline Growth $t_{t}$ & 11,224 & 0.202 & 10,311 & 0.242 & -0.040 & $-5.323 * * *$ \\
\hline CrossList $_{t}$ & 11,224 & 0.075 & 10,311 & 0.059 & 0.015 & $4.515^{* * *}$ \\
\hline
\end{tabular}

${ }^{*}$ Indicates significance at the $10 \%$ level (two-tailed).

** Indicates significance at the 5\% level (two-tailed).

${ }^{* * *}$ Indicates significance at the $1 \%$ level (two-tailed).

This table reports the results of univariate analysis on the Mean and MeanDiff of the two sample groups.

defined in the model (1). The $t$-values for differences in means are based on $t$-tests.

Two-sample variables are measured over year $t$ and

Table 4. Corporate cash holding and idiosyncratic risk.

\begin{tabular}{lll}
\hline & $(1)$ & $(2)$ \\
& $I R_{t+1}$ & $I R_{t+1}$ \\
\hline Cash $_{t}$ & $0.055^{* * *}$ & $0.027^{* * *}$ \\
& $(7.05)$ & $(4.30)$ \\
IRt & & $0.219^{* * *}$ \\
Size $_{t}$ & & $(28.99)$ \\
& & $-0.044^{* * *}$ \\
Age $e^{*}$ & & $(-23.03)$ \\
& & $-0.018^{* * *}$ \\
Lev $_{t}$ & & $(-3.56)$ \\
Roa $_{t}$ & & $0.083^{* * *}$ \\
& & $(7.08)$ \\
Frst & & -0.033 \\
& & $(-0.88)$ \\
& & $0.080^{* * *}$
\end{tabular}


(6.80)

Growth $_{t}$

$0.018^{* * *}$

(5.81)

CrossList

$0.033^{* * *}$

(4.28)

$G D P_{t}$

$1.410^{* * *}$

(18.31)

_cons

$1.505^{* * *}$

(60.85)

(31.44)

$N$

21,535

21,535

Industry_fixed_effect

YES

YES

Year_fixed_effect

YES

YES

Adjusted $\mathrm{R}^{2}$

0.253

0.333

${ }^{*}$ Indicates significance at the $10 \%$ level (two-tailed).

${ }^{* *}$ Indicates significance at the 5\% level (two-tailed).

*** Indicates significance at the $1 \%$ level (two-tailed).

This table presents the results from the ordinary least squares regression of the impact of corporate cash holding on idiosyncratic risk. The dependent variable

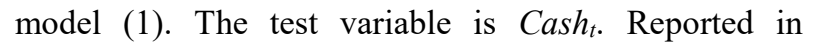
parentheses are t-values based on robust standard errors clustered by firm.

$I R_{t+1}$ is measured over year $t+1$ and defined in the

Table 5. This table reports the results of our robustness test.

\begin{tabular}{|c|c|c|c|}
\hline & (1) & (2) & (3) \\
\hline & $I R_{t+1}$ & $I R_{t+1}$ & $I R_{t+1}$ \\
\hline \multirow[t]{2}{*}{ Cash $_{t}$} & $0.017^{* *}$ & $0.031^{* * *}$ & $0.027^{* * *}$ \\
\hline & (2.08) & $(5.20)$ & $(4.23)$ \\
\hline \multirow[t]{2}{*}{$I R_{t}$} & $0.029^{* * *}$ & $0.218^{* * *}$ & $0.218^{* * *}$ \\
\hline & (4.07) & $(28.95)$ & $(28.92)$ \\
\hline \multirow[t]{2}{*}{ Sizet $_{t}$} & $-0.026^{* * *}$ & $-0.044^{* * *}$ & $-0.043^{* * *}$ \\
\hline & $(-6.64)$ & $(-23.03)$ & $(-21.34)$ \\
\hline \multirow[t]{2}{*}{$\mathrm{Age}_{t}$} & $-0.044^{*}$ & $-0.018^{* * *}$ & $-0.018^{* * *}$ \\
\hline & $(-1.67)$ & $(-3.45)$ & $(-3.49)$ \\
\hline \multirow[t]{2}{*}{ Lev $_{t}$} & $0.057^{* * *}$ & $0.085^{* * *}$ & $0.082^{* * *}$ \\
\hline & (3.53) & $(7.26)$ & (6.98) \\
\hline Roa $_{t}$ & $0.067^{*}$ & -0.035 & -0.032 \\
\hline
\end{tabular}




\begin{tabular}{|c|c|c|c|}
\hline & $(1.67)$ & $(-0.94)$ & $(-0.86)$ \\
\hline \multirow[t]{2}{*}{$F r s_{t}$} & $0.181^{* * *}$ & $0.080^{* * *}$ & $0.083^{* * *}$ \\
\hline & $(6.90)$ & $(6.77)$ & $(6.90)$ \\
\hline \multirow[t]{2}{*}{ Growtht } & $0.017^{* * *}$ & $0.018^{* * *}$ & $0.018^{* * *}$ \\
\hline & $(5.67)$ & $(5.82)$ & $(5.76)$ \\
\hline \multirow[t]{2}{*}{ CrossList $t_{t}$} & -0.008 & $0.033^{* * *}$ & $0.038^{* * *}$ \\
\hline & $(-0.18)$ & $(4.28)$ & $(4.78)$ \\
\hline \multirow[t]{2}{*}{$G D P_{t}$} & $2.528^{* * *}$ & $1.417^{* * *}$ & $1.419^{* * *}$ \\
\hline & $(14.96)$ & $(18.41)$ & $(18.06)$ \\
\hline \multirow[t]{2}{*}{$S O E_{t}$} & & & -0.002 \\
\hline & & & $(-0.59)$ \\
\hline \multirow[t]{2}{*}{$B i g 4 t$} & & & $-0.014^{*}$ \\
\hline & & & $(-1.73)$ \\
\hline \multirow[t]{2}{*}{ Gender $r_{t}$} & & & 0.003 \\
\hline & & & $(0.66)$ \\
\hline \multirow[t]{2}{*}{ Aget } & & & -0.008 \\
\hline & & & $(-0.93)$ \\
\hline \multirow[t]{2}{*}{ Isdualityt } & & & -0.016 \\
\hline & & & $(-1.56)$ \\
\hline \multirow[t]{2}{*}{ cons } & $1.129^{* * *}$ & $1.501^{* * *}$ & $1.514^{* * *}$ \\
\hline & $(8.74)$ & (31.37) & $(25.31)$ \\
\hline $\mathrm{N}$ & 21,535 & 21,535 & 21,531 \\
\hline Industry_fixed_effect & NO & YES & YES \\
\hline Year_fixed_effect & YES & YES & YES \\
\hline Firm_fixed_effect & YES & NO & NO \\
\hline Adjusted $\mathrm{R}^{2}$ & 0.316 & 0.333 & 0.333 \\
\hline \multicolumn{4}{|l|}{${ }^{*}$ Indicates significance at the $10 \%$ level (two-tailed). } \\
\hline \multicolumn{4}{|l|}{${ }^{* *}$ Indicates significance at the $5 \%$ level (two-tailed). } \\
\hline \multicolumn{4}{|l|}{${ }^{* * *}$ Indicates significance at the $1 \%$ level (two-tailed). } \\
\hline $\begin{array}{l}\text { Column (1) is the result of controlling the company's } \\
\text { individual effects. Column (2) is the result of replacing } \\
\text { the cash holding variable. Column ( } 3 \text { ) is the result of } \\
\text { adding omitted correlated variables. The dependent }\end{array}$ & \multicolumn{3}{|c|}{$\begin{array}{l}\text { variable } I R_{t+l} \text { is measured over year } t+1 \text { and defined in } \\
\text { models }(1) . \text { Reported in parentheses are } t \text {-values based } \\
\text { on robust standard errors clustered by firm. }\end{array}$} \\
\hline
\end{tabular}


Table 6. The regression results controlling for some possibly omitted variables.

\begin{tabular}{|c|c|c|c|c|c|c|c|c|}
\hline & (1) & (2) & (3) & (4) & (5) & (6) & (7) & (8) \\
\hline & $S O E$ & Big4 & High Ins & High Growth & NON SOE & NON Big4 & Low Ins & Low Growth \\
\hline \multirow[t]{2}{*}{ Casht } & 0.012 & 0.014 & $0.019^{* *}$ & $0.022^{* *}$ & $0.029^{* * *}$ & $0.025^{* * *}$ & $0.034^{* * *}$ & $0.028^{* * *}$ \\
\hline & $(1.00)$ & $(0.49)$ & $(2.04)$ & $(2.15)$ & $(3.88)$ & (3.87) & (3.97) & $(3.58)$ \\
\hline \multirow[t]{2}{*}{$I R_{t}$} & $0.250^{* * *}$ & $0.327^{* * *}$ & $0.229^{* * *}$ & $0.192^{* * *}$ & $0.188^{* * *}$ & $0.210^{* * *}$ & $0.198^{* * *}$ & $0.234^{* * *}$ \\
\hline & $(22.88)$ & $(10.46)$ & (21.70) & (16.79) & $(18.21)$ & $(27.26)$ & (18.69) & $(24.25)$ \\
\hline \multirow[t]{2}{*}{ Size $_{t}$} & $-0.049^{* * *}$ & $-0.048^{* * *}$ & $-0.045^{* * *}$ & $-0.048^{* * *}$ & $-0.035^{* * *}$ & $-0.042^{* * *}$ & $-0.043^{* * *}$ & $-0.041^{* * *}$ \\
\hline & $(-19.83)$ & $(-7.50)$ & $(-18.84)$ & $(-15.74)$ & $(-12.05)$ & $(-20.85)$ & $(-14.00)$ & $(-18.65)$ \\
\hline \multirow[t]{2}{*}{$\mathrm{Age}_{t}$} & -0.001 & -0.029 & $-0.015^{* *}$ & $-0.016^{* *}$ & $-0.027^{* * *}$ & $-0.021^{* * *}$ & $-0.027^{* * *}$ & $-0.019^{* * *}$ \\
\hline & $(-0.13)$ & $(-1.55)$ & $(-2.05)$ & $(-1.98)$ & $(-4.29)$ & $(-3.89)$ & $(-3.63)$ & $(-2.95)$ \\
\hline \multirow[t]{2}{*}{ Lev $_{t}$} & $0.119^{* * *}$ & $0.198^{* * *}$ & $0.116^{* * *}$ & $0.093^{* * *}$ & $0.041^{* * *}$ & $0.072^{* * *}$ & $0.043^{* * *}$ & $0.078^{* * *}$ \\
\hline & $(7.01)$ & $(4.41)$ & $(7.02)$ & $(4.65)$ & $(2.61)$ & $(6.01)$ & $(2.71)$ & $(5.64)$ \\
\hline \multirow[t]{2}{*}{$\operatorname{Roa}_{t}$} & 0.034 & -0.110 & -0.072 & -0.015 & -0.078 & -0.027 & 0.019 & -0.032 \\
\hline & $(0.60)$ & $(-0.86)$ & $(-1.39)$ & $(-0.21)$ & $(-1.56)$ & $(-0.69)$ & $(0.35)$ & $(-0.67)$ \\
\hline \multirow[t]{2}{*}{$F r s_{t}$} & $0.072^{* * *}$ & 0.006 & $0.070^{* * *}$ & $0.094^{* * *}$ & $0.117^{* * *}$ & $0.089^{* * *}$ & $0.067^{* * *}$ & $0.072^{* * *}$ \\
\hline & $(4.26)$ & $(0.14)$ & $(4.23)$ & $(5.09)$ & $(6.96)$ & (7.33) & $(3.20)$ & $(5.04)$ \\
\hline \multirow[t]{2}{*}{ Growth $_{t}$} & $0.020^{* * *}$ & 0.015 & $0.020^{* * *}$ & $0.014^{* * *}$ & $0.018^{* * *}$ & $0.018^{* * *}$ & $0.013^{* * *}$ & -0.009 \\
\hline & $(4.65)$ & $(0.90)$ & (4.99) & (3.89) & $(4.31)$ & $(5.69)$ & $(2.65)$ & $(-0.76)$ \\
\hline \multirow[t]{2}{*}{ CrossListt $_{t}$} & $0.033^{* * *}$ & $0.040^{* * *}$ & $0.027^{* * *}$ & $0.044^{* * *}$ & $0.046^{* * *}$ & $0.039^{* * *}$ & $0.048^{* * *}$ & $0.028^{* * *}$ \\
\hline & $(3.97)$ & $(2.68)$ & $(3.09)$ & $(3.91)$ & $(2.71)$ & $(4.19)$ & $(3.42)$ & $(3.16)$ \\
\hline \multirow[t]{2}{*}{$G D P_{t}$} & $1.698^{* * *}$ & $1.029^{* * *}$ & $1.603^{* * *}$ & $1.448^{* * *}$ & $1.331^{* * *}$ & $1.445^{* * *}$ & $1.247^{* * *}$ & $1.397^{* * *}$ \\
\hline & $(15.68)$ & $(4.17)$ & (15.10) & (11.26) & (11.03) & $(17.87)$ & $(10.95)$ & $(14.52)$ \\
\hline \multirow[t]{2}{*}{ _cons } & $1.452^{* * *}$ & $1.628^{* * *}$ & $1.461^{* * *}$ & $1.633^{* * *}$ & $1.405^{* * *}$ & $1.485^{* * *}$ & $1.607^{* * *}$ & $1.427^{* * *}$ \\
\hline & $(21.70)$ & $(9.96)$ & (23.64) & $(21.59)$ & $(18.61)$ & $(29.26)$ & (20.09) & $(25.29)$ \\
\hline $\mathrm{N}$ & 9872 & 1293 & 11345 & 7600 & 11663 & 20242 & 10190 & 13935 \\
\hline Industry_fixed_effect & YES & YES & YES & YES & YES & YES & YES & YES \\
\hline Year_fixed_effect & YES & YES & YES & YES & YES & YES & YES & YES \\
\hline Adjusted $\mathrm{R}^{2}$ & 0.419 & 0.468 & 0.356 & 0.318 & 0.267 & 0.322 & 0.313 & 0.340 \\
\hline
\end{tabular}

${ }^{*}$ Indicates significance at the $10 \%$ level (two-tailed).

${ }^{* *}$ Indicates significance at the 5\% level (two-tailed).

*** Indicates significance at the $1 \%$ level (two-tailed).

This table reports the results from the ordinary least squares regression of the impact of corporate cash holding on idiosyncratic risk controlling for some possibly omitted variables. The dependent variable $I R_{t+1}$ is measured over year $t+1$ and defined in models (1). 
The test variable is $\operatorname{Cash}_{t}$. Reported in parentheses are tvalues based on robust standard errors clustered by firm.

\section{CONCLUSIONS}

Using a unique data set of corporate cash holding by China's public firms, we examine the impact of corporate cash holding on idiosyncratic risk. We find that corporate cash holding in China is positively associated with idiosyncratic risk after controlling other idiosyncratic risk determinants. Further analyses demonstrate that the impact of corporate cash holding on idiosyncratic risk is more pronounced in firms that are non-SOEs, non-Big 4 auditors, having lower institutional shareholdings, and a lower growth rate.

In general, our findings provide support to the notion that a high level of cash holding has a high opportunity cost, which sometimes reflects weak corporate governance and agency problems. Many firms tend to hold enough cash and cash equivalents due to transactional motive, precautionary motive, and speculative motive. Nevertheless, we can see that the benefits of holding cash in China are often less than its opportunity cost.

Our study adds to the growing literature on corporate cash holding and its effect on idiosyncratic risk. We concentrate on the role of corporate cash holding in influencing idiosyncratic risk and provide new evidence on the economic consequences of corporate cash holding. Our research enriches the role of corporate cash holding in corporate governance. Our results are beneficial to firms and investors and guide them in determining the appropriate cash holding level.

\section{REFERENCES}

[1] Opler, T., Pinkowitz, L., Stulz, R., \& Williamson, R. (1999). The determinants and implications of corporate cash holdings. Journal of financial economics, 52(1), 3-46.

[2] Myers, S. C., \& Majluf, N. S. (1984). Corporate financing and investment decisions when firms have information that investors do not have. Journal of financial economics, 13(2), 187221.

[3] Jensen, M. C., \& Meckling, W. H. (1976). Theory of the firm: Managerial behavior, agency costs and ownership structure. Journal of financial economics, 3(4), 305-360.
[4] Campbell, J. Y., Lettau, M., Malkiel, B. G., \& Xu, Y. (2001). Have individual stocks become more volatile? An empirical exploration of idiosyncratic risk. The journal of finance, 56(1), 1-43.

[5] Dennis, P., \& Strickland, D. (2004). The determinants of idiosyncratic volatility. Unpublished working paper, University of Virginia.

[6] Bennett, J. A., \& Sias, R. W. (2006). Why companyspecific risk changes over time. Financial Analysts Journal, 62(5), 89-100.

[7] Brown, G., \& Kapadia, N. (2007). Firm-specific risk and equity market development. Journal of Financial Economics, 84(2), 358-388.

[8] Lee, D. D., \& Faff, R. W. (2009). Corporate sustainability performance and idiosyncratic risk: A global perspective. Financial Review, 44(2), 213237.

[9] Liu, C., \& Wang, S. (2021). Investment, idiosyncratic risk, and growth options. Journal of Empirical Finance, 61, 118-138.

[10] Irvine, P. J., \& Pontiff, J. (2009). Idiosyncratic return volatility, cash flows, and product market competition. The Review of Financial Studies, 22(3), 1149-1177.

[11] Keynes, J. M. (1936). The general theory of interest, employment and money.

[12] Miller, M. H., \& Orr, D. (1966). A Model of the Demand for Money by Firms. The Quarterly journal of economics, 80(3), 413-435.

[13] Han, S., \& Qiu, J. (2007). Corporate precautionary cash holdings. Journal of corporate finance, 13(1), 43-57.

[14] Lian, Y., Sepehri, M., \& Foley, M. (2011). Corporate cash holdings and financial crisis: an empirical study of Chinese companies. Eurasian Business Review, 1(2), 112-124.

[15] Hamada, R. S. (1969). Portfolio analysis, market equilibrium and corporation finance. The Journal of Finance, 24(1), 13-31.

[16] Claessens, S., Djankov, S., Fan, J. P., \& Lang, L. H. (2002). Disentangling the incentive and entrenchment effects of large shareholdings. The journal of finance, 57(6), 2741-2771. 